\title{
Um ponto de encontro que frutificou
}

\author{
A fruitful meeting ground
}

\author{
Cláudio Laks Eizirik* \\ * Professor associado, Departmanto de Psiquitria e Medicina Legal, Universidade Federal do Rio Grande do Sul (UFRGS), Porto Alegre, \\ RS. Membro efetivo e analista didata, Sociedade Psicanalítica de Porto Alegre. Ex-editor, Rev Psiquiatr RS.
}

\begin{abstract}
“Após alguns anos de silêncio, surge uma nova Revista de Psiquiatria em nosso meio. Partindo da experiência adquirida nos últimos números da Revista de Psiquiatria Dinâmica, a última que circulou entre nós, parte dos membros do Conselho Editorial daquela publicação, acrescida da adesão de novos colegas e estimulados todos pelo apoio da diretoria da Sociedade de Psiquiatria do Rio Grande do Sul, decidiram aceitar o desafio de publicar uma revista desta natureza."

Assim comecei o editorial do primeiro número de nossa Revista $^{1}$, a seguir expressando o desejo de que tal tentativa frutificasse; mais adiante, explicando a razão de ser aquele um número temático sobre "A família e a saúde mental", acrescentei que também aludia ao que "talvez em outros tempos pudesse ser chamado de a família psiquiátrica gaúcha. Mesmo aceitando as características dinâmicas e amplamente multiplicadoras da instituição familiar, e as inevitáveis fragmentações e antagonismos daí decorrentes, a intenção da Revista de Psiquiatria é servir de ponto de encontro científico, em que as observações, experiências e indagações que nos trazem nossa especialidade possam ser levantadas e debatidas em seus múltiplos aspectos".
\end{abstract}

Ao receber, há poucos dias, o amável convite do atual editor Paulo Oscar Teitelbaum para escrever este editorial comemorativo aos 30 anos da Revista, não só passei a revisitar antigos e atuais números da mesma, como a ser visitado por inúmeras lembranças de pessoas, situações, locais, sentimentos e ideias.

Na qualidade de secretário do Centro de Estudos Luis Guedes, na longínqua década de 70, participei de uma reunião na sede da Associação de Psiquiatria do Rio Grande do Sul, que na época se localizava num edifício da Salgado Filho, na qual o Dr. Marcelo Blaya, então diretor da Clínica Pinel, comunicou que sua instituição decidira editar sua própria revista, dessa forma desfazendo o acordo pelo qual era publicada a Revista de Psiquiatria Dinâmica, editada conjuntamente pela Pinel, pelo Centro de Estudos Luís Guedes (CELG) e pela Associação de Psiquiatria do Rio Grande do Sul, e de cujo
Conselho Editorial eu participava. Algum tempo depois, o então presidente da Associação, Dr. Hans Ingomar Screen e o seu secretário científico, Dr. José Ricardo Pinto de Abreu, convidaram-me para ser o primeiro editor de uma nova publicação, que seria o órgão científico oficial da Associação. Formamos um Conselho Editorial, composto por Antonio Carlos Jardim Pires, Cláudio Maria da Silva Osório, Ivete Enk, José Ricardo Pinto de Abreu, Juarez Guedes Cruz e Maria Lucrecia Scherer Zavaschi, e convidamos para formar o Conselho Consultivo alguns dos mais destacados psiquiatras da época, os doutores Carlos Gari Faria, Darcy Abuchaim, David Zimmermann, Hans Schreen, Isaac Pechansky, Manoel Albuquerque, Milton Shansis, Odon Carneiro Monteiro e Roberto Pinto Ribeiro.

E começamos a nos reunir semanalmente, planejando, montando, discutindo, criando seções, trocando opiniões, coletando trabalhos, em suma, tentando dar à luz um novo ser no qual colocamos o melhor de nossas ideias e esperanças, ajudados pela presença meiga e eficiente da secretária Dalva dos Anjos e da expertise em inglês da nossa colega e amiga Cristina Heuser.

Assim, em março de 1979, surgiu a Revista de Psiquiatria do Rio Grande do Sul, com vários trabalhos sobre o tema da família e da saúde mental, uma curiosa sessão de "avalie seus conhecimentos", resenhas bibliográficas, notícias das atividades científicas e uma preciosa conferência do saudoso professor Roberto Pinto Ribeiro sobre "a psiquiatria como ciência", seu discurso de paraninfo dos formandos da XVIII Turma do Curso de Especialização em Psiquiatria da Universidade Federal do Rio Grande do Sul. Lembro com nitidez aquela ocasião em que o Roberto, com sua eloquência e inteligência habituais, passeou pelo tema proposto, defendendo um projeto científico mais rigoroso para nossa especialidade e concluindo desta forma: "recentemente, o professor David Zimmermann, utilizando habilmente a defeituosa importação para as ciências da saúde dos cursos de mestrado e de doutorado, está iniciando, com a colaboração de outros docentes, 
estudos avançados de psiquiatria, que poderão vir a ser etapa preliminar e fonte de matéria-prima para o projeto científico que acabei de esboçar. Pode ser que, com sua concretização, amanhã consigamos melhor integrar o aspecto técnico com o científico, que seja possível elevar o padrão científico de nossa participação nos conclaves regionais e nacionais e que surjam revistas psiquiátricas respeitadas e regularmente publicadas, onde a psiquiatria brasileira possa realmente intercomunicar suas observações e experiências". Após mais alguns números publicados, deixei a editoria da Revista, que, a partir de 1981, teve como editores os Drs. Ivete Enk, Aldo Luiz Coelho Borges Duarte, Luiz Carlos Mabilde, Jair Rodrigues Escobar, Jussara dal Zot, Sérgio Lewkowicz, José Carlos Calich, Edgar Diefenthaeler, Gisele Gus Manfro, César Brito, Jacó Zaslavsky, Flávio Shansis, Carmen Keidann e Paulo Oscar Teitelbaum.

Mas, na verdade, nunca me afastei de fato da Revista. Ora como membro de seu Conselho Consultivo, ora participando de suas bem montadas atividades científicas, ora sugerindo ou opinando quando consultado por qualquer razão, e sempre que possível enviando trabalhos para publicação, mas principalmente recebendo, lendo e guardando cada número em lugar destacado de minha biblioteca, o que sinto pela Revista é um carinho e um orgulho de ter feito parte de sua história de 30 anos.

As previsões de nosso amigo Roberto se confirmaram, e, ao longo desses 30 anos, os sucessivos editores e seus colegas foram melhorando, ampliando, qualificando, enriquecendo, diversificando, tornando a Revista uma referência nacional e internacional. Ao longo desses 30 anos, o mundo, nossa cidade, nosso Estado e nosso país, a psiquiatria, nossa Associação de Psiquiatria do Rio Grande do Sul, a AMRIGS, todos mudaram de forma significativa.
Folheando os números que se acumulam agora à minha frente, é como se viajasse no tempo, pois a Revista conta a história de nossa psiquiatria, sua fecunda colaboração com a psicanálise, o surgimento de novas técnicas e abordagens, as questões polêmicas debatidas, a evolução da saúde mental, as entrevistas ou trabalhos dos mais destacados pensadores de nossa área e de áreas vizinhas, os desenvolvimentos das neurociências, resenhas de livros que vão formando o pensamento vivo de nossa área, o surgimento e a expansão da pesquisa em suas diversas formas e versões, a evidência do crescimento de nossos programas de pós-graduação, as previsões sobre os futuros desenvolvimentos, o surgimento de novos nomes, novas faces, novas ideias.

Talvez mais do que tudo, de fato, seja essa a grande dimensão a ser celebrada numa data tão significativa: o que na época eu havia chamado de a família psiquiátrica gaúcha se ampliou, diversificou-se, fragmentou-se, enfrentou dolorosas cisões, abrigou antagonismos, testemunhou desencontros, reencontros, perdas, mortes, ao mesmo tempo que registrava novas faces, renovadas ideias, inesperados caminhos e uma admirável capacidade de manter, desenvolver e ampliar um legado que não deixa de ser fertilizado a cada número. A Revista, dessa forma, abriga, integra, contém distintas tendências, áreas, abordagens, visões, enfoques, possibilidades.

Se eu pudesse falar com aquele antigo editor do primeiro número e seus queridos amigos do Conselho Editorial, poderia dizer-lhes que esse foi, de fato, um ponto de encontro que frutificou.

\section{Referência}

1. Eizirik C. Editorial. Rev Psiquiatr RS. 1979;1(1):2. 